\title{
Bee Killers, Mallophora bomboides (Wiedemann), Mallophora orcina (Wiedemann), and Malophora nigra Williston (Insecta: Diptera: Asilidae) ${ }^{1}$
}

\section{G. J. Steck ${ }^{2}$}

\section{Introduction}

Three large predaceous robber flies of the genus Mallophora occur in Florida. Mallophora bomboides (Wiedemann) is known as the "Florida bee killer," M. orcina (Wiedemann) as the "southern bee killer," and M. nigra Williston as the "black bee killer" (Bromley 1950). Two other species have been recorded from Florida: $M$. rex Bromley and $M$. chrysomela Bromley. Structurally, there is nothing to distinguish them from M. bomboides (Wiedemann), and they are considered to be color variants of the latter. Also, M. nigra Williston may be merely a wholly-black color variant of $M$. bomboides (Cole and Pritchard 1964).

At least 20 species in seven genera of asilid flies in the southeastern United States prey on various Hymenoptera, including honey bees (Apis mellifera L.). Of these, $M$. orcina is the most prominent, with $80 \%$ or more of its diet comprised of honey bees (Bromley 1946). Instances of economic losses to beekeepers due to the depredations of asilid bee killers are sporadic, but Florida is one of the few states where such losses have been reported (Bromley 1950).

\section{Distribution and Phenology}

Mallophora bomboides occurs in the southeastern United States including North Carolina, South Carolina, Georgia, Florida, Alabama and Mississippi. Florida county records (Florida State Collection of Arthropods (FSCA)) include Alachua, Clay, Dade, Flagler, Gadsden, Highlands, Hillsborough, Indian River, Levy, Martin, Nassau, Palm Beach, Pinellas, Polk, Putnam, Taylor, Volusia; also Duval and Orange (Bromley 1950). Flight time in Florida is from April through December, though they are most common in late summer.

Mallophora orcina occurs in the eastern U.S. from Florida north to Ohio and west to Missouri and Arkansas. Florida county records (FSCA) include Alachua, Broward, Clay, Columbia, Dade, Duval, Liberty, Monroe, Nassau, Okaloosa, Orange, Polk,

1. This document is EENY-315 (originally published as DPI Entomology Circular No. 366), one of a series of Featured Creatures from the Entomology and Nematology Department, Florida Cooperative Extension Service, Institute of Food and Agricultural Sciences, University of Florida. Published: March 2004. This document is also available on Featured Creatures Website at http://creatures.ifas.ufl.edu. Please visit the EDIS Website at http://edis.ifas.ufl.edu. Additional information on these organisms, including many color photographs, is available at the Entomology and Nematology Department website at http://entnemdept.ifas.ufl.edu/.

2. G. J. Steck, Florida Department of Agriculture and Consumer Services, Division of Plant Industry, Gainesville, FL.

The Institute of Food and Agricultural Sciences (IFAS) is an Equal Employment Opportunity - Affirmative Action Employer authorized to provide research, educational information and other services only to individuals and institutions that function without regard to race, creed, color, religion, age, disability, sex, sexual orientation, marital status, national origin, political opinions or affiliations. For information on obtaining other extension publications, contact your county Cooperative Extension Service office. Florida Cooperative Extension Service / Institute of Food and Agricultural Sciences / University of Florida / Larry R. Arrington, Interim Dean 
Santa Rosa, Sarasota, Wakulla; also Dixie and Pasco (Cole and Pritchard 1964), Columbia and Putnam (Bromley 1950). Flight time in Florida is from April through August, though they are most common in mid-summer.

Mallophora nigra is uncommon. FSCA county records include only Alachua, Duval, Highlands, and Volusia. It is apparently even more rare outside of Florida, having been recorded only from "N.C." (Cole and Pritchard 1960), presumably North Carolina. Flight time in Florida is from July through September.

\section{Description}

Members of this genus in Florida are large, robust flies. The wings are smoky brown and the body has dense patches of black and yellow or white hairs. Bee killers resemble bumblebees and carpenter bees in shape and coloration. They generally mimic all of the five bumblebee species occurring in Florida (Stange 1992). They make a beelike hum or buzz when flying (Linsley 1960).
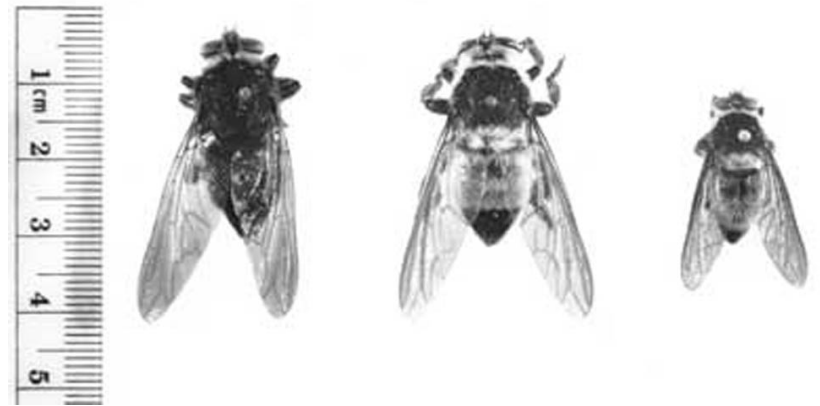

Figure 1. Left to right: The "black bee killer," Mallophora nigra Williston; the "Florida bee killer," M. bomboides (Wiedemann); and the "southern bee killer," M. orcina (Wiedemann). Credits: Photograph by: Jeffrey Lotz, FDOACS-DPI

\section{Biology}

Adults typically occur in open habitats, often in the vicinity of apiaries. They perch on stalks of weeds or on tips of shrubs from which they launch their attack (Brower et al. 1960). Prey are primarily social bees and wasps, including honey bees, bumble bees, carpenter bees, Polistes and Vespa wasps. Honey bees may be particularly suitable as prey because of their slow flight, local abundance, and appropriate body size (Poulton 1906). Eggs are laid into the soil. Specific feeding habits of larvae of the species discussed here are unknown, but larvae of other Mallophora species are ectoparasites on scarabaeid beetle grubs in the soil (Knutson 1972).

\section{Key to the Mallophora of Florida}

1. Abdomen and scutellum wholly black-haired . .................... Mallophora nigra

1'. Abdomen and scutellum with white or yellow hairs ................. 2

2. Basal four or five abdominal tergites densely covered with yellow hairs; and remaining segments wholly with black hairs; ventrum of abdomen wholly black haired. Average body length about $20 \mathrm{~mm}$. . . . . ................. Mallophora orcina

2'. Basal three abdominal tergites densely covered with yellow hairs, 4 th and 5th tergites with black hairs, and final 2 segments with pale hairs; ventrum of abdomen with yellow hairs. Average body length about $25 \mathrm{~mm}$..... Mallophora bomboides

\section{Selected References}

Bromley SW. 1946. Bee-killing Asilidae of the southeastern states (Diptera). Proceedings of the Entomological Society of Washington 48: 16-17.

Bromley SW. 1950. Florida Asilidae (Diptera) with description of one new species. Annals of the Entomological Society of America 43: 227-239.

Brower LP, Brower JVZ, Westcott PW. 1960. Experimental studies in mimicry. 5. The reactions of toads (Bufo terrestris) to bumblebees (Bombus americanorum) and their robberfly mimics (Mallophora bomboides), with a discussion of aggressive mimicry. The American Naturalist 94: 343-355.

Cole FR, Pritchard AE. 1964. The genus Mallophora and related asilid genera in North America (Diptera: Asilidae). University of California Publications in Entomology 36: 43-100.

Knutson LV. 1972. Pupa of Neomochtherus angustipennis (Hine), with notes on feeding habits of robber flies and a review of publications on 
morphology of immature stages (Diptera: Asilidae).

Proceedings of the Biological Society of Washington

85: 163-178.

Linsley EG. 1960. Ethology of some bee- and wasp-killing robber flies of southeastern Arizona and western New Mexico (Diptera: Asilidae). University of California Publications in Entomology 16: 357-381.

Poulton EB. 1906. Predacious insects and their prey. Transaction of the Entomological Society of London 1906: 323-409.

Stange LA. 1992. The bumble bees of Florida (Hymenoptera: Apidae). Florida Department of Agriculture \& Consumer Services, Division of Plant Industry, Gainesville. Entomology Circular No. 353. $2 \mathrm{p}$. 